\title{
The Effects of Poor Financial Information Systems on the Long Term Sustainability of Local Public Services. Empirical Evidence from the Catalan Municipalities
}

\author{
E. Garcia-Alegre \\ G. Lopez-Casasnovas \\ Department of Economics \& Business. Pompeu Fabra University ${ }^{(*)}$
}

\begin{abstract}
In this paper we describe the existence of financial illusion in public accounting and we comment on its effects for the future sustainability of local public services. We relate these features to the lack of incentives amongst public managers for improving the financial reporting and thus management of public assets. Financial illusion pays off for politicians and managers since it allows for larger public expenditure increases and managerial slack, these being arguments in their utility functions. This preference is strengthen by the short time perspective of politically appointed public managers. Both factors run against public accountability.

This hypothesis is tested for Spain by using an unique sample. We take data from around forty Catalan local authorities with population above 20,000 for the financial years 199398. We build this data basis from the Catalan Auditing Office Reports in a way that it can be linked to some other local social and economic variables in order to test our assumptions.
\end{abstract}

The results confirm that there is a statistical relationship between the financial illusion index (FI as constructed in the paper) and higher current expenditure. This reflects on important overruns and increases of the delay in paying suppliers, as well as on a higher difficulties to face capital finance. Mechanisms for FI creation have to do among other factors, with delays in paying suppliers (and thereafter higher future financial costs per unit of service), no adequate provision for bad debts and lack of appropriate capital funding either for reposition or for new equipments. For this, it is crucial to monitor the way in which capital transfers are accounted in local public sheet balances. As a result, for most of the Municipalities we analyse, the funds for guaranteeing continuity and sustainability of public services provision are today at risk.

Given managerial incentives at present in public institutions, we conclude that public regulation recently enforced for assuring better information systems in local public management may not be enough to change the current state of affairs

Literature Classification: H72, H74, H81, M14.

Keywords: public management, financial information systems, financial illusion, and Spanish local authorities.

\footnotetext{
${ }^{(*)}$ - Mail address: guillem.lopez@upf.edu This author acknowledges financial support in this research field from SEC2003-05045/ECO
} 


\section{INTRODUCTION}

In most of OECD countries over the last decades, conventional accounting information systems have been threat by the development of new Information Technologies. Potentials for better budget reporting have improved a lot (see P. Heller, 2003). The aim of improving public accountability through better information is indeed in the core of the new public management (Lopez et. al. 2003). Despite this, implementation depends on the incentives of managers and politicians and things are much less clear in this arena.

Under models of bureaucratic behaviour and fiscal illusion (Niskanen, 1971) ${ }^{1}$, it is plausible to assume that lack of transparency may be there to stay. As it helps to hide inefficiency, poor financial reporting may favour managerial slack against public interest.

Despite the fact that the former assumptions may be extended to public administration in general, our interest here is to test some particular propositions related to the creation of Financial Illusion (FI) at the local public sector level. Mayston et al (1992) have shown that this is an appropriate field of analysis given a larger diversity in the existing practices.

We confront then the effects of FI on local public budgets, and the absence of incentives amongst public managers for a better financial information system to improve the management of publics assets, on a sample of forty two Catalan municipalities ${ }^{2}$ along the 1993-98 period. Data are taken from the Sindicatura de Comptes de Catalunya (The Catalan Auditing Commission) on actual settled expenditure and revenues.

In the first section of the paper we build the notion of FI from the common theory of fiscal illusion. In section 2 we construct a FI index specifically related to the levels of underreporting the actual costs of public services. This refers to the delay of payments to creditors (on cash-based accountancy criteria), lack of accounting for depreciation costs, upgrading the existing equipments and the absence of provision of financial reserves for doubtful public credits. All these factors help to create an illusive 'cash surplus' that feeds public expenditure and managerial slack. In other words, these accounting practices for hiding less visible spending needs help to create the financial illusion that additional more visible expenditure are still possible. This goes against the sustainability of the public services in the long term. But short, and not long term, is the main concern of politicians. In this sense, they may easily collude with managers for the purpose of expenditure increases. We correlate in section 3 those accounting practices to the level of expenditure overruns, debt finance on total revenues, and as a result to some indicators of the sustainability of local services. The 'sustainability' criterion is approached by the difference between estimated capital needs and observed accumulated capital revenues plus the margins to raise additional taxes and debt). Finally we conjecture on how this situation favours local politicians and public managers and we conclude that in order to rebalance the present

\footnotetext{
1 - A recent survey can be found in Hacienda Pública Española 164-(1/2003) 'Organizaciones burocráticas e ineficiencia X: Una revisión de modelos’ A. Rodríguez y J. Suárez. Pps 83-109.

2 - In order to homogenise our sample, given the high disparity in size and budgets of Spanish local authorities, we have taken data only for those with populations of over 20,000 .
} 
situation we need to reinforce rules and provide incentives from an evidence-basis public accountability policy point of view.

\section{ON FISCAL ILLUSION}

The topic of financial illusion and its relevance in public management has been traditionally discussed in the context of fiscal illusion and public expenditure growth. For this purpose, three broad strategies can be pursued to manipulate the citizen (median voter) preferences: First, political actors and bureaucrats may try to show that the tax-price of public sector services appear to be lower than actually is (Miller and Moe, 1983). Second, they may find desirable to foster the idea that the median voter is in receipt of larger real income increases as a result of tax/ expenditure decisions (Miller, 1977). Third, politicians and bureaucrats can attempt to alter the preferences of the voters to raise the absolute value of the marginal rate of substitution between public supplied goods and the rest (Cullis and Jones, 1998).

In more general terms, Puviani (1903) developed different notions of illusion, being the most common that of having individuals to 'feel good' about themselves' ${ }^{3}$. Fiscal illusion is then frown on complex revenue structures and on the most visible benefits of expenditure. In addition, debt illusion failing individuals to realise that when debt is issued their income is affected to the tune of the present discounted value of future tax liabilities may be an important factor too ${ }^{4}$.

Howe ver, testing for FI has proved to be a rather more difficult task. In this sense, Oates (1988) suggests that although several 'illusions' are plausible in public management, the empirical support for them is not overwhelming. Moreover, given revenue endoge neity, competing plausible hypotheses may go alongside some rather 'ad hoc' theories.

Our paper tries to contribute to this arena by offering evidence on the reasons for FI in the provision of local public services. We relate FI to the absence of sound financial and economic information on the part of local politicians and public managers. In this sense FI undoubtedly shelters the lack of transparency. We cannot however disentangle whether FI is the cause or the effect of misreporting information for public accountability, since no causality test can be adopted. In any case, both elements allow for increasing public expenditure at the cost of a poor management of the public assets which affects the financial sustainability of the services in the future.

\section{II.- HYPOTHESIS BUILDING}

This paper is grounded on the following evidence: Despite (i) the development of new powered Technological Information Systems, (ii) a greater concern on the economic and

\footnotetext{
3 - No need probably to expand this argument. Puviani wrote his Teoria della Illusione Finanziaria in 1903 !

4 - A good summary on this can be found in the corres ponding Chapter of 'Public Finance and Public Choice'

J. Cullis and P. Jones. Oxford, second edition, 1998.
} 
social consequences of the public intervention in modern societies, and (iii) the acceptance in democracy of greater social accountability of public expenditure, incentives to implement accurate financial reporting methods on public sector activity seem to be absent in the public management field.

Our hypotheses to explain why this happens are built on:

\section{- The absence of incentives for a more accurate financial reporting}

1-Public managers in Spain have several reasons for not improving budgetary or managerial information given the way in which they are paid (not performance-related) and appointed (many of them politically dependent). In this context, any better information reporting may create counterproductive rachet effects: the evidence on poor performance may be used against managers' interests, more than in their benefit, and it may cause political embarrassment too. Since public managers in Spain are nowadays more political than customer orientated, risk aversion behaviour would go against innovation in information systems and transparency.

2- At the institutional level, the reasons for politicians not to request better financial information are related to:

i) the higher risk of losing marginal (discretionary) expenditure, given the existing asymmetries and budget rigidities ${ }^{5}$;

ii) the pitfalls derived from changes in the accountancy practices and then from a potential misinterpretation of the data under a more conservative accountancy practices.

All this reflects on the lack of identification of the actual unit costs of service provision, price variance in input purchases (from different tendering methods and procurement policies), output performance variability (from changes in the organisation of the production function) and on final outcomes assessments (derived from several forms of public control).

3- Lack of accurate information on the financial and economic situation has larger costs at the long than at the short term. This last is the most relevant term for political purposes. Indeed, poor financial reporting may risk the capacity for maintaining the services provision at medium and long term by endangering its sustainability over time, precisely when they will need to be adjusted to new circumstances. However, this usually is not the main political concern.

We will approach this lack of responsibility in public expenditure by the level of budget overruns and by the ratio of debt to total local revenues

\footnotetext{
5 - To prove that you are 'a good guy' and then taking a bit of the marginal resources available proves to be more difficult than loosing a bit of a ctual resources already spent due to the fact you are identified as a 'bad guy'.
} 


\section{The financial illusion hypothesis.}

FI is based in this paper on the following premises

(i) From a Public Choice point of view, local politicians look for satisfying the greatest amount of citizens' demands, since this is likely to win voters' support, and avoiding the increase in taxes (or at least the perception of such). Citizens are, in general, most concerned with the present rather than on the future effects of policies, as to require more information on balanced present expenditure and future revenues. Transparency would require to increase awareness on the long term consequences of new budget initiatives with regard to the key sources of expenditure pressure and of the limits on increasing the tax burden ${ }^{6}$.

(ii) Benefits for managers from FI are: short-term sustainability of public services is not under question and marginal expenditure increases are possible. In fact, generally speaking, reducing costs in an underhanded way does not negatively affect the results (the benefit and losses account), and help the fiction of a (constant) net balance of the existing local assets. In addition, FI helps lower local price increases in public services.

The items of the balance sheet accounts that offer a larger potential for under-valuation are those related to delaying payments to creditors and an insufficient provision for asset reposition and risky debtors. This is due either to the fact that these are expenses that affect third-parties, with not much political pressure since they are regular creditors of the administration not willing to risk reputation, or because it does not seem to exist clear-cut criteria for interpreting the treatment of capital assets in public accounting systems. Moreover in none of these cases external auditing has been made up to day compulsory: auditing is random, and expected sanctions for having followed unsound practices are low.

We will approach precisely the FI derived from the lack of a correct depreciation of assets and from the absence of reserves for risky debtors by calculating the difference between the official recorded expenses and those which would result under 'sound' accounting principles, generally accepted either by the private sector or by other agents in the public sector.

\section{-The consequences of FI for an efficient public management}

The relationship between management accounting and strategic behaviour of the organisations has been largely analysed in the literature (E. Caplan, 1971; R. Cooper and R Kaplan, 1988; Chenhall R and D Morris , 1986).

\footnotetext{
6 - An excellent revision on this issue can be found in Peter Heller Who will pay International Monetary Fund 2003. This includes among other measures (i) the assessment of accrued liabilities in the balance sheet, (ii) the tax or primary balance gap (on stochastic scenarios), (iii) net debt measures, (iv) fiscal generational unbalance measures, and (iv) the risk-weighted assessments of the government's assets and liabilities.
} 
As a result of the observations above mentioned, the expected negative consequences of FI are:

(i) Implicit financial costs are larger than those actually collected in local public accounts. On the past, it has been observed (E. Garcia, 1999) that registered costs are lower than actual costs if providers would pay as due with no delays and provisions for bad debts would have been appropriately made. European Union legislation ${ }^{7}$ establishes a maximum period for paying public administration creditors.

We will take this benchmark (three months) in accounting for the difference between the theoretical financial cost related to paying creditors on time and the larger one due to existing delays.

(ii) Future sustainability of local service provision may be at risk as a consequence of the level of current expenditure passed. Capital assets must guarantee the continuity of the service over time. This is eroded by an unsound depreciation policy that does not correctly account for capital utilisation. By following this practice, we either a) apparently reduce costs in the short term (increasing FI and allowing additional spending programs) at the expense of risking financial bankruptcy in the future, or b) issue debt to guarantee capital to sustain the public services (reducing then financial margins for discretionary spending of future generations). Moreover, sustainability requires a minimum financial surplus for adapting public organisations to changing economic environments, and not just to hold capital for 'standing still' 8 .

In order to estimate this factor we alternatively calculate, a) the potential revenue surplus that a municipality has for financing in case additional expenditure other than that required for fulfilling the economic balance. This may result from increasing taxes (if the ratio of the local authority, say, is below the sample average) and from the elasticity of local fiscal revenues from current taxed activity; and b) the revenue raising margins from issuing new debt, given the current levels and the existing limitations.

Both factors try to measure the capability to finance the revenue gap for new investment, in addition to the accumulated municipal savings and central (and European) capital transfers. It approaches the difference between the estimated capital needs and the observed accumulated capital revenues plus the existing capacity to raise additional taxes and debt.

\section{- The sample}

We confront our hypotheses on the effects of FI on financial management by using data from Catalan municipalities along the 1993-98 period, in a comparable data basis from the Auditing Commission.

In order to homogenise our sample, given the disparity in population size and budget levels, we have taken data only for those municipalities with populations over 20,000 . These are

\footnotetext{
7 In Spain, through the 923/ 1985 Bill for the Public Administration Contracts.

8 They may result from public regulation or from adopting what could defined as 'sound economic and financial management practices' in this field.
} 
considered local authorities with enough capability to run the required new information systems. Given data availability we selected finally 42 Catalan municipalities.

\section{- $\quad$ The financial reporting system}

Poor financial and economic reporting has traditionally raised important problems in public management. For instance Hendriksen, in 1981 and Riahi, in 1992, refer to the cases of textile and railways industry in the XIX century, where large profits were paid to shareholders in an undue way. Benefits were defined as the difference between revenue flows and cash payments without considering capital depreciation. These were short-term profits for speculators and final bankruptcy for the remaining asset holders.

In similar terms, long-term financial viability off public services depend on holding real assets. This requires the existence of a balanced equilibrium in order a) to keep physical capital in operation (Lüder, 1993), b) a systemic preventive procedures for quality assurance of the services (Pallot, 1994) and c) those repairs needed to keep the productive capacity of the investment goods up to the time of the reposition, in order to finance an equal or better equip ment. If this is not the case, issuing debt or selling assets for financing the required equipments are the final effects of the former unsound accounting practices. As Anthony (1980) points out, non-profit organisations cannot identify the absence of prof it targets with negligent accountancy in risking the sustainability of the activities of the organisation as a whole.

In the Spanish context, since July 1990, rules for Local Administration Accountancy (ICAL) define a new Information System for budgetary and financial statements in order to build some economic indicators for a better management of public assets. These changes were supposed to be in place in 1992 but the rate of complete reporting is very low even today (see table 1).

Accountancy practices in Spain still allow for the coexistence of the principles of accrual accounting (according to the day accrues the right to receive the revenues and duty are due to be paid) and the 'cash' criteria (the day they are actually paid). But once on of them is chosen, consistency is required. Despite the norm, this purpose is not yet largely guaranteed.

In Catalonia, as in other parts of the Spanish state, local administrations had to implement the new Public Accountant Regime, set up by the several instructions ${ }^{9}$ at the time of presenting the Annual Accounts and the Internal Audit. Its level of implementation is shown in table 1 for local authorities, according to size and year with regard to the actual budget settlement, financial surplus, balance sheet and 'profits and losses' account.

Table 1 Description of the contents of the present financial reporting by the size of the local authorities

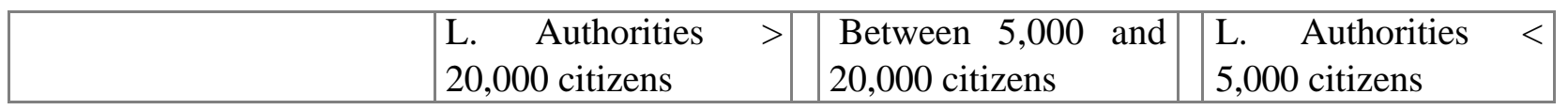

9 - In particular, ICAL Rule 416 and 230, amongst others. 


\begin{tabular}{|l|l|l|l|l|l|l|l|l|l|l|l|l|}
\hline & $\begin{array}{l}199 \\
2\end{array}$ & $\begin{array}{l}199 \\
3\end{array}$ & $\begin{array}{l}199 \\
5\end{array}$ & $\begin{array}{l}199 \\
8\end{array}$ & $\begin{array}{l}199 \\
2\end{array}$ & $\begin{array}{l}199 \\
3\end{array}$ & $\begin{array}{l}199 \\
5\end{array}$ & $\begin{array}{l}199 \\
8\end{array}$ & $\begin{array}{l}199 \\
2\end{array}$ & $\begin{array}{l}199 \\
3\end{array}$ & $\begin{array}{l}199 \\
5\end{array}$ & $\begin{array}{l}199 \\
8\end{array}$ \\
\hline $\begin{array}{l}\text { Number of Local } \\
\text { Authorities }\end{array}$ & 42 & 43 & 45 & 103 & 103 & 114 & 114 & 797 & 798 & 787 & 787 \\
\hline $\begin{array}{l}\% \text { of Local Authorities } \\
\text { having fulfilled the } \\
\text { information: }\end{array}$ & & & & & & & & & & & \\
\hline $\begin{array}{l}\text { Closed budget in } \\
\text { equilibrium }\end{array}$ & 98 & 98 & 100 & 100 & 91 & 95 & 93 & 98 & 54 & 68 & 76 & 82 \\
\hline $\begin{array}{l}\text { Carryover budget = Net } \\
\text { recognised revenues - } \\
\text { Net recognised debts + } \\
\text { cash }\end{array}$ & 100 & 100 & 100 & 89 & 90 & 91 & 96 & 52 & 67 & 76 & 82 \\
\hline $\begin{array}{l}\text { Providing the account of } \\
\text { profits and losses }\end{array}$ & 83 & 88 & 100 & 100 & 82 & 91 & 88 & 94 & 52 & 67 & 76 & 81 \\
\hline $\begin{array}{l}\text { Exhibiting a Balance } \\
\text { sheet }\end{array}$ & 88 & 90 & 98 & 100 & 81 & 91 & 88 & 94 & 52 & 67 & 76 & 82 \\
\hline
\end{tabular}

Source: Own elaboration from "Sindicatura de Comptes de Catalunya".

Notice that the level of financial reporting diminishes with size (from $70 \%$ to $90 \%$ ) and it increases along the years (almost 100\% of Municipalities with 20,000 population and over in 1998).

For this last group (Barcelona City Council was excluded in order not to distort our comparisons), Table 2 shows the degree of FI on the overall current budget revenues. Financial illusion is proxied by the difference between what is accounted for spending on capital reposition and what it should be according to some sounder common practices as those derived from private accountancy ${ }^{10}$. FI potential gives the maximum amount of FI if the observed practices were applied to all public capital (this is, if nothing had been funded for equipment renewal). At any rate, the coefficient of variation as a measure of dispersion (the ratio in $\%$ between the average value and the standard deviation) shows very different situations.

Table 2 The 'financial illusion' factor as a share of current revenues. Financial illusion is approached here by the difference between what is actually accounted for spending on capital reposition and what it should be according to some sounder common practices (see footnote 10)

\begin{tabular}{|l|l|l|lll|l|}
\hline FI (financial illusion) & 1993 & 1994 & 1995 & 1996 & 1997 & 1998 \\
\hline$\%$ & 16,3 & 17,3 & 14,6 & 14,6 & 11,9 & 11,8 \\
\hline coefficient of variation & 66 & 51 & 53 & 53 & 55 & 61 \\
\hline$\%$ FI/FI potential & $90 \%$ & $93 \%$ & $87 \%$ & $82 \%$ & $71 \%$ & $69 \%$ \\
\hline
\end{tabular}

Source: Own calcuhtions from "Sindicatura de Comptes de Catalunya".

Municipalities with more than 20.000 people (Barcelona not included).

10 -See footnote 12. 
As it is shown in Table 2, the FI coefficient is always greater that 10\%, diminishing over time, but with a large internal coefficient of variation. Moreover it can be seen that the ratio between actual and potential fiscal illusion decreases over time: from 90\% up to around $70 \%$ for the last years of the series. Table 3 offers some additional information on the number of Municipalities and the level of FI (less than 5\%, between 5 and 15\%, and more than $15 \%)$.

Table 3 Number of Local Authorities (> 20.000 inhabitants) and level of financial illusion (\% estimated level on current revenues).

\begin{tabular}{|l|l|l|l|}
\hline $\begin{array}{l}\% \text { total financial illusion divided by the } \\
\text { budgeted current revenues }\end{array}$ & 1993 & 1998 \\
\hline Number of municipalities of FI $<5 \%$ & 2 & 5 & 7 \\
\hline $\begin{array}{l}\text { Number of municipalities between 5 and } \\
15 \% \text { of FI }\end{array}$ & 17 & 20 \\
\hline $\begin{array}{l}\text { Number of municipalities with \% of FI } \\
>15 \%\end{array}$ & 20 & 14 \\
\hline
\end{tabular}

Source: Own calculations from "Sindicatura de Comptes de Catalunya".

\section{III.- TESTING AND RESULTS}

The effect of under-reporting financial costs in creating financial illusion is shown in Table 4. Figures reflect the average delay in payments under the hypothesis of linearity in expenditure compelling. Terms are well above the benchmarked three months for the 199395 period and two months thereafter ${ }^{11}$, although they are lowering over time. However internal variation on the average delay for the outstanding credits among Local Authorities is rather stable or increasing.

Table 4 Average delay for the outstanding credits (days).

\begin{tabular}{|l|l|l|l|}
\hline & 1993 & 1995 & 1998 \\
\hline Municipalities(*) & 239,3 & 219,7 & 176,3 \\
\hline Variation coefficient & 58,2 & 57,8 & 67,2 \\
\hline
\end{tabular}

Source: Own calculations from "Sindicatura de Comptes de Catalunya" data.

(*) Amongst those larger than 20.000 .

The estimated financial costs of these delays, weighted by the different term constrain of wages and other type of payments are estimated in Table 5. The financial cost of this form of short-term debt is therefore estimated in 45 days for the 1993-95 period and 30 days thereafter. Most of this cost is not just a 'social opportunity cost' but an extra financial cost paid by the administration, once we plausibly assume that there exists an implicit surcharge from providers on the prices charged for those public supplies with delayed payment.

\footnotetext{
11 The 923/1965 Bill for the State Contracts, section 47, and the13/1995 Bill for the Contracts of the Public Administration, section 100 .
} 
Table 5 Estimated financial cost due to credit outstanding (in euros per capita).

\begin{tabular}{|l|l|l|l|}
\hline & 1993 & 1995 & 1998 \\
\hline Local authorities $\left.(*)^{*}\right)$ & 16.3 & 16.8 & 7.3 \\
\hline Variation coefficient $(\%)$ & 89.1 & 91.3 & 91.1 \\
\hline Interest rate considered $^{12}$ & $9 \%$ & $9 \%$ & $4 \%$ \\
\hline
\end{tabular}

Source: Own calculations from "Sindicatura de Comptes de Catalunya".

(*) Amongst those larger than 20,000.

Finally, table 6 explores tentatively the correlation between financial illusion, payment delays and cash surplus in order to finance additional expenditure. The signs are the expected ones in all the cases but the statistical significance is low.

Table 6 Linear regression statistics (\#).

\begin{tabular}{|l|l|l|}
\hline Credit outstanding & $\begin{array}{l}1993 \quad \text { to } \\
1998\end{array}$ & $\begin{array}{l}1994 \\
1998\end{array}$ \\
\hline Constant & 75.8 & 114.7 \\
\hline $\mathrm{t}$ ratio & $(6.3)$ & $(16.2)$ \\
\hline \% Financial illusion divided by budgeted current revenues & 9.5 & 5.3 \\
\hline $\mathrm{t}$ ratio & $(13.1)$ & $(11.6)$ \\
\hline $\begin{array}{l}\text { Estimated \% Carryover budget divided by budgeted current } \\
\text { revenues (year n-1) }\end{array}$ & - & -2.9 \\
\hline $\mathrm{t}$ ratio & - & $(-25)$ \\
\hline Standard error with estimation & 97.8 & 50.1 \\
\hline Determination coefficient & 0.4 & 0.84 \\
\hline F & - & 540.4 \\
\hline Degrees of freedom & 256 & 212 \\
\hline
\end{tabular}

(\#) Individual values for each observation within periods. 1993 data have some reliability problems we cannot deal with and the exercise is then repeated for the period 1994-98.

Source: Own calculations from "Sindicatura de Comptes de Catalunya" data.

A second large area of hypothesis testing refers to the way that financial illusion expenditure affects the capability to produce public services. This may be due to unsound accounting practices related to depreciation and reserves, as commented.

Table 7 describes some explanatory variables for the variation in the observed equity composition in \% terms on current local revenues, as reflected in the 'profit and losses' account.

\footnotetext{
${ }^{12}$ The basic interest rate of Bank of Spain until 1996. Since 1997. MIBOR 1 year.
} 
Table 7 Explanatory variables for the variation in equity as a $\%$ of current revenues from the 'profit and losses' account (*).

\begin{tabular}{|l|l|l|l|l|l|}
\hline & 1994 & 1995 & 1996 & 1997 & 1998 \\
\hline$\%$ FI /CR & 14.5 & 12.4 & 12.6 & 10.4 & 10.4 \\
\hline & & & & & \\
\hline $\begin{array}{l}\text { Estimated variation in } \\
\text { equity (or net losses) on } \\
\text { CR (\%) }\end{array}$ & 13.9 & 13.6 & 4.6 & 23.6 & 18.0 \\
\hline & & & & & \\
\hline$\%$ EOR & 2.1 & 1.8 & -0.8 & 5.2 & 5.1 \\
\hline$\%$ ECG & 3.1 & 2.2 & 4.1 & 2.0 & 5.3 \\
\hline EOR + ECG & 5.2 & 4.0 & 3.3 & 7.2 & 10.4 \\
\hline & & & & & \\
\hline$\%$ EONPL & 8.7 & 9.6 & 1.3 & 16.4 & 7.6 \\
\hline
\end{tabular}

Source: Own calculations from "Sindicatura de Comptes de Catalunya".

FI: Financial illusion, CR: Current revenues from 'profit and losses' account. EOR: Estimated operating result, ECG: Estimated capital grants. EONPL: Estimated other net losses.

(*) Average of 42 local authorities.

Our calculations show that the weight of the estimated FI on current revenues diminish over the period at the same time that estimated losses with adequate accountancy on total operating result and capital grants are increasing in the last three years.

As commented, the maintenance capability of a particular model for service provision depends on the increase in the equity value (net worth) of the organisation. This depends on the economic results from the activity and on the availability of external capital grants. This capability also has to do not only with the efficiency of the model providing services (see Pina \& Torres, 2002) but with existing safeguards for capital equipments and some other dynamic social constrains (such as non-discriminatory access to services, equality of opportunities, due procedures, etc.)

In a previous paper, Garcia, $1998^{13}$, showed that during the $1992-95$ period for local authorities below 5,000 inhabitants, if we adopted for the public equipments similar criteria on repostion as for private ones, the level of under-funding varied from $40 \%$ to $90 \%$. The absence of an appropriate depreciation policy links to the discussion on how capital grants should be accounted in local public sector balance sheets. Table 8 offers a range of possible interpretations on how to consider capital grants. They affect the net worth of an organisation over time and then the inter-temporal and intergenerational effects (Henke, 1987; GASB, 1989).

\footnotetext{
${ }^{13}$ Garcia Alegre, E. "La inversió en reposició dels Ajuntaments de Catalunya majors de 5.000 habitants". 1992-1995. Mimeo. 1998
} 
Table 8 Different approaches in computing capital grants (CG).

\begin{tabular}{|ll|l|l|}
\hline CG & CG as... & Explanation & Use of capital grant \\
\hline $\begin{array}{l}\text { Capital } \\
\text { grants }\end{array}$ & $\begin{array}{l}100 \% \\
\text { ? equity }\end{array}$ & $\begin{array}{l}\text { CG are considered a sort } \\
\text { of intergenerational } \\
\text { contribution }\end{array}$ & $\begin{array}{l}\text { The CG only finance the growth of the } \\
\text { equipment or its upgrading }\end{array}$ \\
\cline { 2 - 4 } & $\begin{array}{l}\text { ? equity are only partially } \\
\text { considered } \\
\text { intergenerational } \\
\text { contribution }\end{array}$ & $\begin{array}{l}\text { The CG are partially applied to the renewal of } \\
\text { existing equipment and partially to new } \\
\text { equipment }\end{array}$ \\
& $\begin{array}{l}\text { no equity } \\
\text { considered as operating } \\
\text { revenue of the period }\end{array}$ & $\begin{array}{l}\text { The CG only finance the renewal of existing } \\
\text { equipment }\end{array}$ \\
\hline
\end{tabular}

Source: Own elaboration

A first option consists of valuing the capital grants as the ownership of all generations in society. In this sense, reposition costs should be self-financed and those grants should be devoted to improve the quality of the services. The second alternative considers that since grants are tax financed at some general level (say at the State or at the European Union level) they are also partly paid by local taxpayers. Therefore, full self-finance of reposition costs is not grounded and we need to blend financially both (new and existing) capital components. Thirdly, it may also be considered that there is a correspondence between what taxpayers finance locally and the share they receive from the overall central grants. This would require that the full amount of the grant to be considered as current revenue for the purpose of maintaining the net assets of the present administration.

In practice, financial liabilities and capital grants commonly finance the equipment renewal. If the financial resources related to the depreciation charges are devoted to the reduction of the existing financial liabilities, the intergenerational equilibrium is better preserved. In this sense, accumulated funds could be used to lower the need for financing capital by issuing net debt and the existing margin can be then used for financing the reposition investment whenever required.

In Table 9 we explore whether the capacity for delivering public services at an appropriate quality level holds in our sample over time. Under the first and third criteria for valuing capital grants we detect important differences, with an increasing dap along the years: The ratio between the row 1 and 3 changes from less that $10 \%$ up to $25 \%$ (with a $40 \%$ change over the 199498 period). The conclusion is sensitive on whether we accumulate capital grants and reduce them from existing assets.

Table 9 Share of capital grants in total equity composition (euros per capita).

\begin{tabular}{|l|l|l|l|l|l|l|}
\hline Local authorities $\left(^{*}\right)$ & 1994 & 1995 & 1996 & 1997 & 1998 & $\begin{array}{l}\text { Variation } \\
1998-1994\end{array}$ \\
\hline $\begin{array}{l}\text { Equity without adjustment per capita } \\
(1)\end{array}$ & 418 & 460 & 480 & 533 & 625 & 207 \\
\hline $\begin{array}{l}\text { Accumulated Capital Gains (ACG) per } \\
\text { capita (2) }\end{array}$ & 22 & 45 & 73 & 103 & 145 & 123 \\
\hline
\end{tabular}




\begin{tabular}{|l|l|l|l|l|l|l|}
\hline Equity minusACG per capita (3) & 396 & 415 & 407 & 430 & 480 & 84 \\
\hline
\end{tabular}

Source: Own calculations from "Sindicatura de Comptes de Catalunya". ACG: Accumulated capital grant.

(*) Average population of local authorities above 20,000 people (Barcelona excluded).

Finally, economic sustainability is estimated by (i) an indicator on the margins each local administration have, in order to react against changes impelling expenditure increases, by adjusting their local tax levels to the average of similar authorities (Table 10), and (ii) issuing debt in order to invest in reposition of equipment, obsolete assets, large repairs and new investments. This margin is defined as the difference between existing debts and the maximum debt allowed by law. Today the stated rule requires a positive economic result for the current final budget settlement and that the existing total debt does not exceed $110 \%$ of all the current revenues effectively collected in the last budgetary exercise ${ }^{14}$ (Table 12 and 13).

Table 10 Estimated average level of the 'sustainability margin' (SM) as a share of the current revenues.

\begin{tabular}{|l|l|l|l|l|l|}
\hline & 1994 & 1995 & 1996 & 1997 & 1998 \\
\hline Average & 5.3 & 4.9 & 3.4 & 9.9 & 11.8 \\
\hline coefficient. of variation & 7.6 & 9.8 & 8.3 & 12.0 & 10.9 \\
\hline
\end{tabular}

Source: Own calculations from "Sindicatura de Comptes de Catalunya".

For the first indicator (table 10) we observe a rather low margin for tax increases for those below average levels, increasing over time, but with a constant (high) coefficient of variation. The regression in Table 11 shows the expected negative signs between the 'financial illusion' index and the sustainability indicator, despite the low statistical significance. Simple correlation is particularly high for the three first years of the sample (table 11).

Table 11 Estimated regression between the sustainability margin (SM) and the financial illusion (FI) index: Two periods: 1994-96 and 1996-98.

\begin{tabular}{|l|l|l|}
\hline & SM96 & SM98 \\
\hline Constant & 13.7 & 17.3 \\
\hline $\mathrm{t}$ ratio & 6.0 & 4.6 \\
$\begin{array}{l}\text { Foefficient of FI9496 and } \\
\text { FI ratio }\end{array}$ & -0.9 & -0.5 \\
\hline $\mathrm{R}^{2}$ & -5.0 & -1.6 \\
\hline Degrees of freedom & 0.39 & 0.36 \\
\hline
\end{tabular}

\footnotetext{
${ }^{14}$ The 39/1988 Bill, section 54.1 and 54.2 was modified by the 50/1998 Bill section 59 . The new benchmark on issuing local public debt is more accurate than the old one. This was stated as an overall limitation based on the rule that the financial costs of the existing debt could not exceed $25 \%$ of the current local-revenues without distinguishing between the nature of these revenues and the prevailing rate of interest. At present, The Budget Stability Bill has come to further restrict the former situation.
} 
\begin{tabular}{|l|l|}
\hline Simple correlation coefficient & -0.62 \\
\hline
\end{tabular}

$-0.25$

Source: Own calculations from "Sindicatura de Comptes de Catalunya" data.

FI9496 and FI9698 = Average financial illusion between 1994 and 1996, and between 1996 and 1998.

$\mathrm{SM}=$ Sustainability margin as a percentage of the current revenues for the corresponding year.

In Table 12 we collect the $\%$ of total debts on current revenues and in Table 13 we regress the index for FI and the margins for issuing additional debt

Table 12 Estimated percentage of total debts on current revenues.

\begin{tabular}{|l|l|l|l|}
\hline & 1993 & 1995 & 1998 \\
\hline Average & 115 & 113 & 115 \\
\hline Variation coefficient (\%). & 57 & 58 & 62
\end{tabular}

Source: Own calculations from "Sindicatura de Comptes de Catalunya" data.

Table 13 The estimated regression of the financial illusion index (FI) on the debt margin (DM).

\begin{tabular}{|l|l|l|}
\hline Constant & $\begin{array}{l}\text { DM96 } \\
40.3\end{array}$ & $\begin{array}{l}\text { DM98 } \\
51.0\end{array}$ \\
\hline$t$ ratio & 3.2 & 3.4 \\
\hline Coefficient of FI9496 and & -4.5 & -5.3 \\
FI9698 & & \\
\hline $\mathrm{t}$ ratio & -4.5 & -4.1 \\
$\mathrm{R}^{2}$ & 0.34 & 0.29 \\
\hline Degrees of freedom & 40 & 40 \\
\hline Correlation coefficient & -0.58 & -0.54 \\
\hline
\end{tabular}

Source: Own calculations from "Sin dicatura de Comptes de Catalunya" data.

FI9496 or FI9698 = Average financial illusion between 1994 and 1996, and between 1996 and 1998

$\mathrm{DM}=$ Debt margin as a percentage of the current revenues for the corresponding year.

In contrast to table 11, in table 13 we observe, rather surprisingly, that for the second indicator (potential debt margins), it is observed a zero capability for issuing net debt along all the period if new rules (expected to be implemented in 1999) were applied. This should be an important cause of concern. The correlation again is unambiguously negative between this result and an important number of local authorities 'living' in larger financial illusion contexts as we have hypothesized in this paper.

Finally, we assumed that financial llusion was in the manager advantage. To test this requires more data we do not have (managerial turnover, financial slack, etc.). With our data, preliminary results are in table 14 . It shows that FI makes for an irrelevant carryover 
budget or economic net profit (loss), either positive or negative at convenience. In this case, social prestige and higher expenditure levels related to what 'it looks like' a positive result and it may allow for a 'free' disposal of the accumulated budget surplus, certainly increases with FI, particularly for the 1994-96 period, as it has been argued in the paper.

Table 14 Managerial effects from financial illusion (FI).

\begin{tabular}{|c|c|c|c|c|}
\hline \multirow[t]{2}{*}{$\begin{array}{l}\text { Number of } \begin{array}{r}\text { Local } \\
\text { Authorities }\end{array} \\
\text { importance of } \mathrm{FI}(+/-)\end{array}$} & \multicolumn{2}{|c|}{$\begin{array}{l}\text { Average FI } 1994-96 \\
\% \text { of cases benefiting from FI }\end{array}$} & \multicolumn{2}{|c|}{$\begin{array}{l}\text { Average FI of } 1996-98 \\
\% \text { of cases benefiting from } \\
\text { FI }\end{array}$} \\
\hline & $\begin{array}{l}\text { Social prestige } \\
+ \\
\text { OR }\end{array}$ & $\begin{array}{l}\text { Higher } \\
\text { expenses + } \\
\text { FDASB }\end{array}$ & $\begin{array}{l}\text { Social } \\
\text { prestige + } \\
\text { OR }\end{array}$ & $\begin{array}{l}\text { Higher } \\
\text { expenses } \\
\text { FDASB }\end{array}$ \\
\hline 10 & $70 \%$ & $70 \%$ & $50 \%$ & $70 \%$ \\
\hline 20 & $55 \%$ & $65 \%$ & $50 \%$ & $70 \%$ \\
\hline 30 & $50 \%$ & $60 \%$ & $53 \%$ & $63 \%$ \\
\hline
\end{tabular}

Source: Own calculations from "Sindicatura de Comptes de Catalunya".

FI: Financial Illusion, OR: operating result, FDASB: Free disposal of the accumulated budget surplus

\section{IV.- CONCLUSION}

We conclude from our analysis that financial illusion shows a clear positive relationship with total local expenditure. Mechanisms for FI creation have to do with, among other factors, with delays in paying to suppliers (with then higher future financial costs per unit of service), no adequate provision for bad debts and with the lack of appropriate capital funding either for reposition or for financing new investment. For this latter feature, it is extremely important to check on how capital grants are accounted in public financial statements.

No incentives for public managers seem to exist for changing the situation and therefore improving financial and economic reporting in Public Administration. On the contrary, it may be the case that incentives go in the other direction: hiding information and avoiding a more accurate reporting system and citizens' accountability make overall for an easier life for politicians and public managers, at least in the short term.

On the whole the results confirm that there is a statistical relationship between the financial illusion index (as constructed in the paper) and expenditure overruns as measured by the delayed payment period for suppliers, as well as by the deficit in local capital depreciation. For this, it proves to be very relevant the way in which capital grants are accounted in public balances. As a result of the existing practices, for most of the Municipalities in our sample, funds for guaranteeing continuity and sustainability of public services provision are indeed at risk. For most of the analysed cases we find that no financial margins exist for rebalancing the situation either by issuing net debtsor by raising taxes in order to guarantee the sustainability of local services provision, and then re-instaure a sounder capital finance 
Since it is observed that public managers and politicians benefit from financial illusion, we conclude that new local public regulation may not be enough to change the current state of affairs and that better incentives should be provided with regard to the way in which public services are managed and financed.

Bibliographic references

Antony, R.N. (1980). Making sese of non-business accounting. Harvard Business Review, vol 58 n$^{0}$ 3, pp.83-93.

Caplan E.H. (1971) 'Management accounting and behavioural science' Massachusetts: Addison-Wesley Publish.

Cooper R. and R. Kaplan (1988) 'How cost accounting systematically distorst product costs. Management Accounting, april pp. $20-27$.

Chenhall R.H. and Morris D. (1986) 'The impact of structure, environment and interdependence on the perceived usefulness of management accountuing systems' The Accounting Review vol LXI, 1 January pps. 16-35

Fuertes I. and Vela Bargues, J.M. (2000). 'La contabilidad de la administración local en Europa: Heterogeneidad y armonización'. Revista española de financiación y contabilidad, vol. XXIX, núm.105, pp. 657-686.

Garcia, Eugeni (1999) Los efectos de la ilusión financiera en la gestión económicofinanciera de las A.A. P.P. Col-lecció de tesis doctorals microfitxades. Núm 3714. Universitat de Barcelona.

Governmental Accounting Standards Board (GASB) (1989). 'Measurement focus and basis of Accounting -Governmental Fund Operating Statements'. Statement $\mathbf{n}^{0} 11$.

Hendriksen, Eldon S. (1981). Teoría de la contabilidad. Unión Tipográfica Editorial.

Henke, E.O. (1987). 'Governmental Financial Statements-Generational Equity Reporting'. The Government Accountants Journal, summer, pp.18-22.

López Casasnovas, G. (1995). Instrumentos al servicio de la eficiencia en la gestión pública. V Congreso Nacional de Economía. Las Palmas. 
López Casasnovas, G. et al. (2003). Los nuevos instrumentos de la gestión pública. Colección Estudios Económicos no 31. La Caixa; 301 pages.

Lüder, Klaus. (1993). Una comparació internacional de les pràctiques de comptabilitat del sector públic.Actius fixes, depreciació $i$ manteniment. Ponencia presentada en las jornadas "Tendencias y evolución de la Administración pública: A la búsqueda de una major eficacia. Barcelona 10-12 de febrero. Sindicatura de Comptes de Catalunya.

Lüder, Klaus. (1995). Governmental capital asset accounting. A survey Study. The Federation des Experts Comptables Europeens (FEE). Published by: The chartered institute of public finance and accountancy (CIPFA). London.

Mayston D (1992) Capital Accounting, user needs and the foundations of a conceptual framework for public sector financial reporting' Financial Accountability and Management, 8(4) Winter pps 22- 240.

Miller G. J, and T.M. Moe (1983) Bureaucrats, legislators and the Size of the Government, American Political Science Review, 77: 297-322.

Miller G. J. (1977), Bureaucratic compliance as a game on the uUnit Square, Public Choice, 29; 37-54.

Niskanen, W. (1971). Bureaucracy and representative government, Aldine-Atherton, Chicago.

Niskanen, W. (1975). 'Bureaucrats and politicians', Journal of Law and Economics, 18, pp. 617-643.

Oates, W.E. (1988) 'On the nature and measurement of fiscal illusion; A Survey, pp 65-82 in G. Brennan et al (eds.) Taxation and Fiscal Federalism. Australian Univ. Press.

Pallot, J. (1994) “Accounting for infraestructure assets: Theory and Practice in New Zealand”. Paper prepared for the CIGAR worshop. IVIE. Valencia. 1994.

Pallot, June (1996). 'Innovations in national government accounting and budgeting in New Zealand'. Research in Governmental Non-profit Accounting, vol. 9, pp. 323-348. 
Pina, V \& L. Torres (2002) 'Propiedad y organización en la prestación de servicios públicos municipales: Análisis y evidencias empíricas comparadas' Cuadernos Económicos, no 16 Fac de C. Económicas dela Univ. de Zaragoza.

Prior T.E. (1990) 'Designing your new cost system is simple but not easy' Journal of Cost management pp 43-47

Puviani, A. (1903). Teoría della Illusione finanziaria. Ed. Remo Sandron. Palermo.

Riahi Belkaoui, Ahmed, (1992). Accounting Theory. Academic Press. University of Illinois at Chicago.

Servei d'Informació Econòmica Municipal. SIEM (1995-1997). Memoria. Diputación de Barcelona.

Sindicatura de Comptes de Catalunya (1993-1998). Compte general de les corporacions locals. Barcelona.

Vela, J.M. (1992). Conceptos y Principios de Contabilidad Pública. ICAC. MEH. 